\title{
FORUM: \\ Forum on the State of the Field of Social Gospel Studies ${ }^{*}$ EDITORS' NOTE
}

$L$ IKE puritanism, protestantism, Catholicism, and Christianity itself, the term "social gospel" refers to phenomena more heterogeneous than a simple name may suggest. Thus like these other terms, "social gospel" refers to a range of theories and practices that the essays in this forum begin to describe. At the same time, however, as these essays also indicate, distinctions between the social gospel and other modern forms of protestant Christianity may be sharper than previous historiography suggests.

In his contribution to the forum, Christopher H. Evans emphasizes the totalizing idealism of the social gospel. Evans calls attention to a broad array of American leaders mostly forgotten today, as well as to socio-economic concerns that distinguished these proponents of social Christianity from other theological liberals. Developing this theme, Heath W. Carter differentiates the economic progressivism of the social gospel from liberal theology as many Americans in the late-nineteenth and early-twentieth centuries understood it, citing important instances in which important representatives of liberal theology took stands against labor. Wendy J. Deichmann turns our attention to grassroots support for the social gospel, arguing that its impact can be more accurately assessed when understood as a popular movement rather than, as it is often taught today, as an intellectual movement among highly educated theologians. Rima Lunin Schultz builds on these contributions to show how fully Jane Addams embodied the practical idealism of the social gospel. As Schultz argues, Addams's thorough identification with social Christianity explains why she had so little interest in theology.

Together, these four contributions go a long way in showing that the social gospel had its greatest impact, not on American intellectual life, but on and within social institutions. One implication of this forum may be that the institutions Americans inhabit today reflect the impact of social gospel movement in ways that theology in America does not.

\footnotetext{
*Please note that the title has been corrected since the original publication of this article. An erratum notice detailing this change was also published (DOI 10.1017/S0009640715000463).
} 